\title{
Innovation and Knowledge Management System in Creative Industry: A systematic Literature Review Using Metaanalysis
}

\section{Yanti Mayasari Ginting ${ }^{1}$, Elfindrí2 ${ }^{2}$,Hafiz Rahman², and Dodi Devianto ${ }^{2}$}

${ }^{1}$ Management Department, Sekolah Tinggi IImu Ekonomi Pelita Indonesia, Pekanbaru, Riau, Indonesia

${ }^{2}$ Economic Department, Economic Faculty, Andalas University, Padang, West Sumatera, Indonesia

${ }^{3}$ Management Department, Economic Faculty, Andalas University, Padang, West Sumatera,Indonesia

${ }^{4}$ Mathematics Department, Faculty of Math and Science, Andalas University, Padang, West Sumatera, Indonesia

\section{Abstract}

The aims of this study is mapping current literature regarding innovation that directly or indirectly influences knowledge management system in the organization. This paper uses meta-analysis as the tool of analysis to identify and classify literatures that have been used as sthe foundation of overview regarding innovation and knowedge management system in creative industry. Traditional companies have goals orientations in the form of labor, buildings, land, and financial capital nowadays has changed with the rapidity of competition, competitive intensity, information intensity, market uncertainty, and the use of technology. Knowledge has become an important organizational strategic asset. Creative industry is an industry that empowers innovation to added value that comes from creative people. The existence of creative people in creative industry emphasizes the fact that companies can not build innovative concepts without considering the purpose and motivation of creative people in generating innovative work. Without such considerations The literatures viewed that creative industries can not last long and at risk of losing creative people. The benefit of this research is to understood the concept of innovation as a potencial that affects the implementation of knowledge management system in creative industry.

Keywords: Creative Industry, Innovation, Knowledge Management System, Metaanalysis

\section{Introduction}

Indonesian Government has paid attention to the existence and growth of creative economy in the country. This can be seen with the presence of Badan Ekonomi Kreatif (Bekraf) which is a non-ministerial institution, an independent institution directly responsible to 
the president of the Republic of Indonesia. The presence of Bekraf is expected to deliver benefits in growing the creative economy in Indonesia. Especially with the defined of sub-sector of creative industry that has been set as many as 16 sub sectors, as the previous sub-sector development as many as 14 sub-sectors. [1]

Based on renewable resources generated from Indonesia's human resources, creative industries are expected to become Indonesia's economic milestones due to Indonesia as a country that has the fourth largest population in the world, and Indonesia has many beauty and richness cultures.

Creativity, ideas, talents are strategic assets of creative industries that can be commercialized and tradeable derived from knowledge. Individual knowledge is gained from education, experience, internships, social interaction, community.

Creative industry is an organization that practice various functions to achieve the goals and vision of the organization. So the overall synergy of creative classes within theorganization is the key to success in finding and delivering the needs that match consumer expectations, and increasing market share.

Some literature shows the result that knowledge management will produce and influence innovation. But in a knowledge-based organization it must be realized that innovation is knowledge and is a product of a traded economy then the emphasis is on tacit knowledge. This is very limited in exploration in the literature especially in the creative industry literature.

In a study conducted on the computer games industry, which is the youngest and fastest growing digital industry has examined changes in the management practices of people as a case of companies experienced a distinctive strategic change in the industry began explorative innovation. They argue that maintaining an organizational context conducive to innovation over time risks turning into contests between management and employees, employees (creative workers) and companies, both parties interpret organizational pressures from their different perspectives. The challenge for management is how the organization implements a Knowledge Management System (KMS) in organizations based on individual personal capabilities within an organization. The organization can not work without collaborating with the knowledge of the creative people in it and also without the ability of the organization in performing the functions of the organization, each party synergized to achieve the goals of the organization. [2]

Innovation is the knowledge, the outcome of the experience and the individual learning process that will have an impact on the organization. So Innovation is not generated from the company, but the result of individual tacit knowledge that can be treated as economic and tradable goods (tradable economic goods). Innovative knowledge by 
organizations is acquired, converted, applied, and protected through the implementation of knowledge management processes. In this case the role of individuals is very important in generating ideas and innovative products.

So it is necessary to explore the role of innovation in KMS of the creative industry because knowledge is gained not from the Research \& Development (R\&D) process but derives from the individual it possesses from experience, perseverance, talent (tacit knowledge). In order to empower these innovations, organizations must convert innovations (such as products, processes, services) that consumers need that can provide a large profit margin for the organization [3].

This paper begins with introduction, and then explanation of innovation, after that the KMS literature review, and furthermore review about innovation and KMS, and end with conclusions and direction for further research.

\section{Innovation}

Innovation has long been a mainstay of the industry in order to survive in the competition in the market. Innovation is a representation of customer expectations acquired through the process of creating, developing, and introducing new products, processes and services that benefit consumers in terms of quality, cost, and time.

Innovation relates to something new, developmental and commercial value. In competitive market conditions, innovation will lead to imitations that make long-term innovation no longer a source of profit for the company. This is because the company innovates but never reaches at $100 \%$ optimal point (curve 1) so the company creates the next innovation (curve 2). Innovation as a disrupting economic structure and unceasingly creating new ones. This situation makes the economy never in a balanced condition (disequilibrium). 


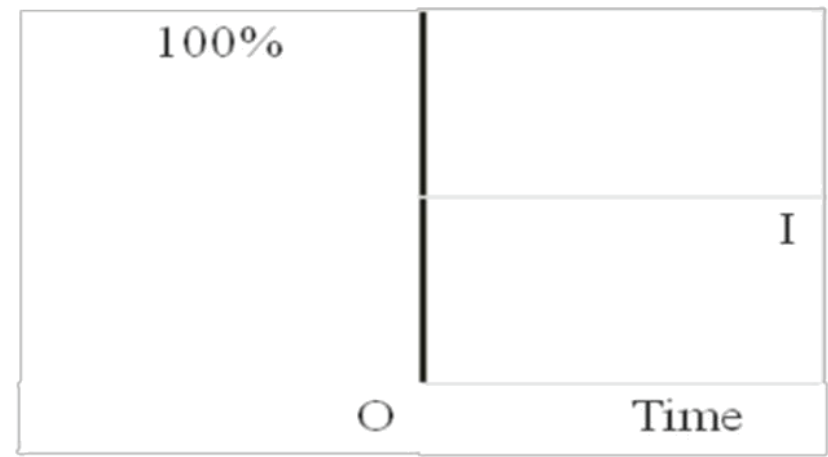

\section{Curve 1}

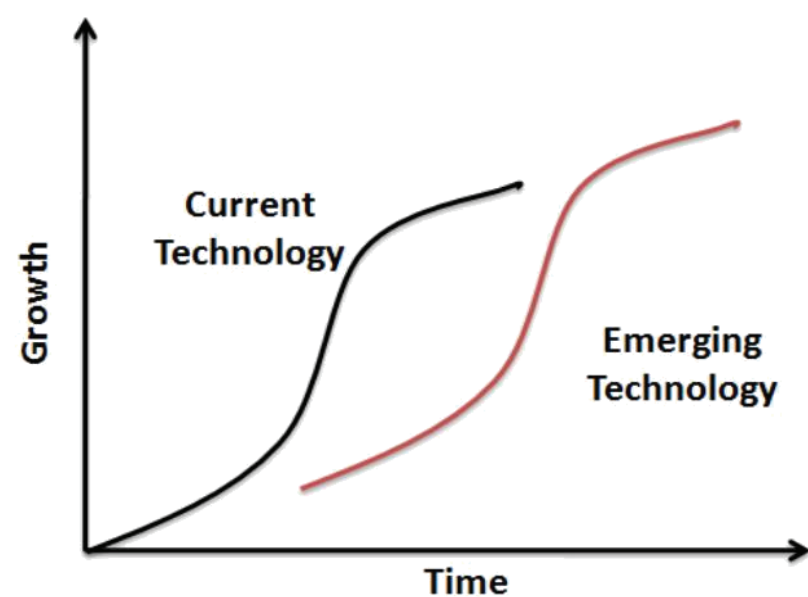

Curve 2

In his article Cumming has done a review of understanding on the word Innovation through previous research studies. Exploring about the development of technology and material as an enabler for the emergence of innovation. Technology as an innovation enabler where new ideas can not be used due to limited technical factors. Through the process of technological refinement gained through practice, experience, perseverance, then ideas that were initially unfeasible or impossible became practicable. The material in use is determined by its availability. Meterial is an important factor that shows the progress of Innovation. Further supporting technology is microelectronica which is used as a very strong control, and has a very wide effect. We gain experience using modern cars with electronic systems that control the amount of fuel delivered, the time of spark to ignite the fuel, the airflow to the engine, the engine speed, and other important parameters monitored or controlled by electronic means [3].

This study is predominantly seeing how innovation arises in creating products. So it can be concluded that the challenge for industries that can drive innovation is like the figures below (;Figure 1): 


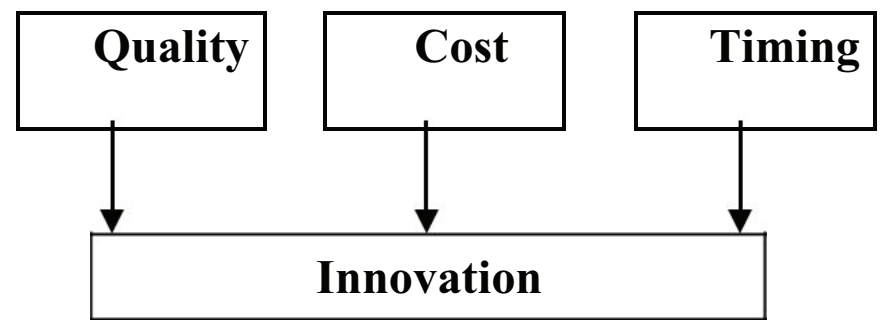

Figure 1: Factors Drivers Technology.

With the explanation as follows:

1. Quality is the ability of a product provide benefits according to consumer expectations.

2. Cost is the overall expenditure calculated from the manufacture of the product that will affect the market competition, profit will be accepted.

3. Timing is an indication of product timing or the amount of time required for the design of new products, developed, manufactured and entered the market.

Many authors have given the definition of innovation and each has its own distinctive. Inniovation is defined as a series of technical steps, industrial and commercial [4]. Innovation as a technological change unit and the definition of Schmookler's technical change as a company that produces goods or services or uses new methods or inputs for it. The important note for this definition is the concept that only the first company to adopt innovation-driven changes, the next adopters are imitators rather than innovators. [5] Kuhn suggests that creativity shapes something out of nothing and innovates it shapes it into products and services.[6] Badawy writes the creativity of bringing something new into being and innovation brings something newly used. [7] Innovation consists of generating new ideas and their implementation into new products, processes, or services, leading to the dynamic growth of the national economy and increasing employment and the creation of pure profit for innovative business enterprises.[8] Innovation as the creation, development, and introduction of new products, processes, or services. [9] For a discovery to be innovative, it must succeed in the marketplace.[10] Innovation Unit states that innovation is the process of taking new ideas effectively and profitably through satisfying customers. [11]

Innovation was originally understood as a process, as the introduction of change. Some regard innovation as the generation of new ideas. Since the late 1960 s the meaning of the term innovation seems to have been perfected. The emphasis of understanding the word innovation incorporates the concept of commercialization that is the result of enhancing business competitiveness, and a growing customer focus. 
Innovation is defined as a special tool for entrepreneurs, with entrepreneurial innovation making use of change as an opportunity (which is the source of innovation) for different businesses or services.[12] Innovation focuses on the idea of creating something new and applying it successfully in the marketplace.[13] Innovation is defined as the process of creating, experimenting, transforming not only the offer but the way in which it deals with the business model, they also define innovation as a process of identified opportunities and utilize them. Innovation is as a new idea, practice, or object.[15] Innovation is not just about having ideas because many people have ideas but have no desire, vision and or knowledge to be able to commercialize them.

Innovation is also about new processes and new ways of doing things that may not be obvious to customers, but adds an important value in delivering the services and products that customers need.[16] Innovation occurs after some time after discovery which is the solution to the problem; innovation is the application of a commercially successful solution.[17] According to Schumpeter, innovation is usually more important than discovery. [18]

Nelson Oly Ndubisi and Iftikhar stated that several organizations have resulted in sustainable competitive advantage through continuous innovation and ability to take advantage of other capabilities of the company. Cumming sees the term innovation as the creation of a new product or process [3], while Knox calls it a new way of providing better quality or value. [20] Innovation is a form of knowledge or the creation of new ideas. [21]

$[22,23]$ Innovation organizational as the adoption of new ideas or behaviors for organizational adopters, involving all dimensions of organizational activity, such as new products or services, new production process technologies, new structures or administration systems and new plans or programs within organizations.

Then according to Garcia-Alvarez innovation is a key driver in successfully deploying Sustainability organizations.[25] Innovation is based on knowledge and environmental, social, and economic criteria allowing the creation of a sustainable basis for competitiveness within organizations.[26] In other words, innovative skills generated by knowledge can play an important role for organizational sustainability.[27] Open Inovation is a value-solving, in which knowledge begins to be acquired through partners, that together they acquire the skills necessary to produce innovation and knowledge because it is complementary.[28] In this case, open inovation is in line with knowledge management [29], which involves the use of mechanisms that help companies manage knowledge as an asset that drives business development [30], that innovation that results in learning and knowledge sharing can help the development of the company [31]. 
Innovation is not just a process of creating new technology or just invention. The need for new innovative formats stems from the difficulty that organizations [32] should innovate through their own (internal) efforts [33], as traditional innovation models use the use of exceptional resources and knowledge [34] arising from their own organizations. In the open knowledge innovation perspective is the masterpiece of the whole process. In particular, the flow of tacit and explicit external knowledge is essential [35]. Open Innovation uses internal and external organizational information flows [36] because to increase innovation, the studied companies open their framework to ideas from external environments [37], customers, suppliers, communities, and their employees. Open Inovation also avoids the previous paradigm of closed innovation to be an obsolete and unstable part for the sustainability of business organizations.

Furthermore, in the research entitled "innovation intelligence and entrepreneur in the fashion industry" conducted by Fatma Genç Ünay, Cemal Zehir stated that fashion business and fashion entrepreneurs require a high level of innovation and entrepreneurship to produce high-performing enterprises.[38] In line with the literature states that innovation improves company performance and contributes to competitive advantage. The study of this creative industry uses Innovation as exploiting commercial ideas and creative input in the fashion industry. Innovation is found in creative and individuals perseverance, not spontaneity and not as an institutionalized activity or an organizational capability. A creative, able to change trends or habits and its existence affects the corporate culture, organizational competence, and innovation management.

Another study conducted a study of how knowledge-based HRM and intelectual capital (IC) were performed on innovation performance by Aino Kianto, Josune Sáenz, Nekane Aramburu. The study used structured survey data collected in Spain in 2014 using Key Informant Tecnique at companies with at least 100 employees. A total of 180 questionnaires were collected. The results of the analysis show that, intellectual capital consisting of human capital, relational capital and structural capital can be used as a mediating variable, human capital positively mediates the relationship between knowledge-based HRM practices on structural capital and relational capital. Structural capital and relational capital mediate the relationship between human capital and innovation performance. Structural capital positively mediates the relationship between knowledge-based HRM practices and innovation performance. The important thing in this study is that innovation is a human ability.[39]

Katsuhito Iwai writes in his paper "Schumpeterian Dynamics An Evolutionary Model of Innovation and Imitation" that Innovation creates a market power that allows innovators to earn a monopoly profit or is called entrepreneurial profit, the drive forming a motive 
for innovative activities and also attracting others to imitate [40]. In the end innovation becomes common and the benefits of such innovation can no longer be enjoyed, until the creation of the next innovation. [41]

Technology is the result of a company's productivity in an industry. Productivity is never lost and keeps the company growing. So that technology is in disequilibrium position. The interaction of the company's growth process and the process of innovation and imitation of technology will shape the evolutionary pattern of the state of industrial technology.

A study by L'ubica Lesáková entitled "Evaluating innovations in small and medium enterprises in Slovakia" states that innovation by small and medium enterprises is part of a knowledge-based economy. The study was conducted in Slovakia with the aim of identifying the main obstacles to developing innovative activities and then formulating recommendations in overcoming these obstacles. Productive businesses are able to dynamically respond to market demand, research and develop on an ongoing basis, innovation and technological change. Company size and innovation capacity have a high correlation, large companies can innovate higher otherwise small companies have low innovation capacity. SMEs in Slovakia are generally innovating mainly using their own funds. Companies that implement technological innovations are mainly done in the automotive and machinery industries, product innovation achieves competitive advantage through changes in products / services offered by the company, process innovation is done through the way products / services are created or shipped.[42]

The study was conducted on 857 samples of small and medium enterprises $160 \%$ industrial companies, $40 \%$ service companies). The results confirm that only 256 SMEs (29\%) apply some innovation activity. Of these 256 small and medium enterprises, 39\% of companies have improved production technology, 14\% SMEs have developed and implemented fairly new products (mostly from industrial production) and 33\% of SMEs have innovated their products / services. As the most important contribution of the innovation activity of SME implementation has identified: increase in turnover (69\%), lower production cost (34\%) and export increase (11\%). The obstacles faced by SMEs in Slovakia are: the lack of financial resources, most companies in Slovakia do not realize or underestimate the importance of innovation in today's global economy, the lack of innovation infrastructure, the participation of small and medium enterprises in networks and groups, in engaging small and medium-sized businesses into innovation activities. Leadership, culture, innovative performance diagnostic tools, training in individual potential development efforts, providing reward systems for employees who contribute to creativity 
development within organizations is a step in creating innovation capabilities within a company.

\section{Knowledge Management System (KMS)}

Knowledge is a vital asset and an important source of any organization.[43]. Knowledge Managemet focuses on corporate strategic goals such as innovation, performance improvement, competitive advantage, and success stories and lessons learned. Therefore, Knowledge Management Systems (KMS) can play an important role in improving organizations and individuals performance.

KMS is considered an organizational memory by utilizing the collective knowledge of the company from one project to another, major investments are made in the technology infrastructure for KMS. However, little is known about the return on investment for KMS, in terms of the impact on employee and organizational performance. [43, 44]

KMS combines: creating and capturing new knowledge, supporting and facilitating content management, and sharing and reusing knowledge to generate value [45]. Therefore, individual contribution, technology, and task structure are the three main aspects of KMS [46]. There is an increasing need within the organization to understand the introduction of the use of KMS and its impact on employee performance from the perspective of these aspects. $[45,47,48]$

Knowledge management (KM) is generally defined as the acquisition, storage, retrieval, application, generation and review of an organization's knowledge assets in a controlled manner [49-53], although the exact definition depends in the context and relevance of a particular business sector in which its application is applied. KM emphasizes changes in the relevance of information according to context and needs. The essence of $\mathrm{KM}$ is the relationship between two dimensions, people and information, mediated by systems and processes.

Successful KMS also need to create an environment that encourages users to seek knowledge for themselves and pull it out from sources inside and outside of company boundaries [54]. KMS works as a mechanism to encourage a culture of knowledge generation, elicitation, transfer and utilization, which characterize the correct learning organization; provides a competitive advantage for organizations to create learning organizations.[55]

Process-based KMS encourages organizational learning through the experience of applying knowledge-producing processes. The application of modeling process to KMS designed is meant to express the explicit and tacit knowledge of business processes. 
By using and developing the intellectual capital of an organization through this processbased KMS, it is ensured that the organization itself which creates knowledge through the application of processes. Although the individual is the one who apply this process, the process model is defined in such a way that knowledge is generated every time a process is implemented.

But in the context of companies where individual exclusive knowledge is not seen as a strategic asset by a company it is true that knowledge is gained through only by the application of research and development (R \& D) and process experience that the company undertakes. In contrast to companies that use individual exclusive knowledge of innovative ideas as commercialized assets such as the creative industry. So Implementation of KMS is a process whereby knowledge is accepted, transferred, maintained, applied, and legally protected by the organization (patented) will be influenced by innovation as the exclusive ability of the individual in the creative industry.

\section{Innovation and KMS in Literature}

Knowledge management is the process of capturing, distributing, and using knowledge effectively.[56] Knowledge management is the basis of the company's capability construction, which underlies the performance of organizational and management processes.

[57] The knowledge base generated from information about customers, markets, competition, and future technology is at the core of product development and operating management systems.[58] Lopes et al. in his research states that knowledge management as a trigger of innovation.[59] Hurley and Hult describe the capacity to innovate a company as a key strategic variable. [60]

In the context of creative industries the most strategic characteristic of a company is organizational creativity. Therefore companies with high levels of innovative capacity in the creative industries should be able to create an environment that encourages and supports creative ideas that produce new products, processes or systems.[61] So as to contribute to the knowledge management system in the creative industry. innovation improves company performance and contributes to competitive advantage [38], from that research in creative industries in the fashion business sector, declared that global fashion business requires advanced management techniques in addition to creativity and high-level innovation given the rapid development of business strategy related to fashion management. But in his research 
[2] states that there is a conflict between the interests of management and creative worker. Management emphasizes efficiency on the other hand creative worker put forward creativity and innovation, so the role of knowledge management in the creative industry is influenced by the capacity of innovation owned by the industry to be able to synergize between creative worker and industry interests.

\section{Conclusion}

Literature has explained that knowledge comes from individuals. Knowledge is divided into two processes namely tacit and explicit knowledge. Tacit knowledge is individual knowledge of the way (know-how) comes from learn, perseverance, experience and insight. Explicit knowledge is standard knowledge derived from printed books, manuals, procedures and guidelines that express information clearly through language, pictures, sounds, or other means of communication.

Innovation is a commercially viable idea. Innovation is a way for organizations to create competitive advantage. In conditions with high intensity of competition today, the application of knowledge-based economy through innovation is an important condition in winning the competition. In a creative industry where knowledge is exclusive, knowledge is hard to imitate or transferred because innovation comes from perseverance, experience, insight into the identity of individual innovation abilities. Innovation is constantly changing along with the development of knowledge gained from the environment, communities, consumers, and markets.

The ability of individual innovation and implementation of KMS has a relationship in transfer and codification of knowledge into the next explicit knowledge of the spiral process of knowledge taking place within the organization. Different with creative industry, knowledge is unique, exclusively integrated into the character, the identity derived from the insights and experiences of the individual (tacit), the transfer of knowledge in the form of the idea of individual (exclusive) innovation is a difficult thing to do (because knowledge is obtained from perseverance, experience and insight) and difficult to codify.

KMS is implemented to achieve competitive advantage, effectiveness and efficiency, improve performance, improve professionalism and reduce risk. The creative industry based on the literature review assumes that knowledge is an organizational strategic asset that makes organizations different and competitive, and not easily imitable (subjective). 
KMS implementation consists of knowledge acquisition process; knowledge acquisition such as getting, searching, generating, creating, capturing, and collaborating to gain knowledge. Knowledge conversion is making existing knowledge useful and utilized in the business environment. Knowledge application is the use of relevant knowledge for the company in creating value. Knowledge protection is the protection of knowledge within an organization from the use or theft of illegal or inappropriate.

Some literature shows how KMS is influenced by factors such as leadership and top management support, organizational culture, and the environment. The exclusivity of individual knowledge has no place in the implementation of KMS. But in the creative industry, knowledge, ideas of innovative ideas are owned exclusively by individuals because knowledge, ideas and ideas are not easy to imitate, transfer, transfer and codify into explicit knowledge. So the application of KMS in the creative industry will be influenced by innovation that is the capacity of innovation owned by individuals exclusively. Then the organization with its proprietary knowledge gained monopoly profits. With innovation, KMS in the creative industry can adjust its knowledge and ability to produce products, processes and services according to market needs and wants, create distinct advantages, and monopolize profits.

\section{Directions for Future Research}

The definition of innovation has evolved from the generation of new ideas to the successful concept of commercialization resulting from increased business competitiveness, and customer focus. In some literature the activity of innovation is seen as a result of the input or proxy of the innovation output such as the number of patented findings. Other measurements using the $R \& D$ measure indicate the budget allocated for innovation activities, but how innovations as tacit skilled labor knowledge plays an important role in generating innovative products, processes and services (exclusively) in influencing knowledge management system implementation of knowledge-based organizations the creative industry needs to be proven further.

Different with organizations that engage in innovative activities through organizational research and development, innovation in the creative industry is a knowledge that is not easily codified. Innovation is a unique idea (not easily imitated), exclusively integrated into character, an identity gained from insight, perseverance, and individual experience (emphasizing tacit knowledge).

Engaging an organization with such exclusive knowledge poses challenges that are different from other organizations in general. Organizations and sources of innovation 
(individuals) have different motivations so for the long-term goals of the organization, individual and organizational innovation knowledge needs to be collaborated.

So in the implementation of KMS in creative industry, individual innovation ability will greatly influence. So further research needs to be validated for the relationship.

\section{Acknowledgement}

This research was fully funded by Lembaga Penelitian dan Pengabdian Masyarakat (LPPM) from Sekolah Tinggi Ilmu Ekonomi (STIE) Pelita Indonesia with contract number 098/VII/LPPM-STIE-PI/2018.

\section{References}

[1] Badan Ekonomi Kreatif Nasional, 2016. Sistem Ekonomi Kreatif Nasional Panduan Pemeringkatan Kabupaten/ Kota Kreatif. Jakarta, Indonesia: Deputi Infrastruktur Badan Ekonomi Kreatif.

[2] Sabine Hotho, Katherine Champion, 2011. Small businesses in the new creative industries: innovation as a people management. Management Decision, Vol. 49 (1), pp. 29-54.

[3] Cumming, Brian S., 1998. Innovation overview and future challenges. European Journal of Innovation Management, Vol. 1 (1), pp. 21-29.

[4] Robertson, R., 1974. Innovation management. Management Decision Monograph, Vol. 12(6), p. 332.

[5] Marquis, D.G., 1969. The anatomy of successful innovations. Innovation, Vol. 1 (1), pp. 35-48.

[6] Kuhn, R.L., 1985 Frontiers in Creative and Innovative Management. Ballinger, Cambridge, MA.

[7] Badawy, M.K., 1988. How to prevent creativity mismanagement. Engineering Management Review, Vol. 16 (2), pp. 60-71.

[8] Urabe, K., 1988. Innovation and Management. Berlin: Walter de Gruyter, New York, NY.

[9] Udwadia, F.E., 1990. Creativity and innovation in organizations. Technological Forecasting and Social Change, Vol. 38 (1), pp. 65-80.

[10] Twiss, B., 1992. Managing Technological Innovation. Pitman, London.

[11] DTI, 1996. Innovation the Best Practice - The Executive Summary. DTI. 
[12] Drucker, P.F., 1985. The Practice of Entrepreneurship, Innovation and Entrepreneurship Practice and Principles. Harper \& Row, New York, pp. 41-188.

[13] Ulijn, Weggeman., 2001. Towards an Innovation Culture: What are its national, corporate, marketing and engineering aspects, some experimental evidence. In: C. Cooper, S. Cartwright and C. Early, eds. Handbook of Organisational Culture and Climate, London: Wiley, pp. 487-517.

[14] Robin Lowe, Sue Marriott., 2006. Enterprise: Entrepreneurship and Innovation Concepts, Contexts and Commercialization. BH (Butterworth-Heinemann) Elsevier, Oxford.

[15] E, Rogers., 1983. Diffusion of Innovations. 3rd edition. The Free Press.

[16] Ann T. Kellogg, et al., 2002. In An Influential Fashion: An Encyclopedia Of Nineteenth and Twentieth Century Fashion Designers and Retailers Who Transformed Dress. Greenwood Press, USA.

[17] C., Clipson., 1991. Managing Innovation". [ed.] Jane Henry and David Walker. Sage Publications.

[18] Craw, Thomas K. Mc., 2007. Prophet of Innovation: Joseph Schumpeter and Creative Destruction. The Belknap Press of Harvard University Press Cambridge, Massachusetts, and London, England.

[19] . Nelson Oly Ndubisi, Khurram Iftikhar, 2012. Relationship between entrepreneurship, innovation and performance: Comparing small and medium-size enterprises. Journal of Research in Marketing and Entrepreneurship, Vol. 14 (2), pp. 214-236.

[20] . Knox, S., 2002. The broadroom agenda: developing the innovative organization. Corporate Governance, Vol. 2 (1), pp. 27-36.

[21] . Chaharbaghi, K. and Newman, 1996. Innovating: towards an integrated learning model.

Management Decision, Vol. 34 (4), pp. 5-13.

[22] . McAdam, R., Armstrong, G., Kelly, B., 1998. Investigation of the relationship between total quality and innovation: a research study involving small organizations. European Journal of Innovation Management, Vol. 1 (3), pp. 139-47.

[23] Urabe, K., Child, J. and Kagono, T., 1998. Innovation and Management: International Comparison. Walter de Gruyter, Berlin; New York.

[24]. Damanpour, F., 1991. Organisational innovation: a meta-analysis of effects of determinants and moderators. Academy of Management Journal, Vol. 34 (3), pp. 555-90. 
[25] . García-Alvarez, M.T., 2015. Analysis of the effects of ICTs in knowledge management and innovation: the case of Zara Group. Comput. Hum. Behav, Vol. 51 (Part B), pp. 994-1002.

[26] Buys, L., Mengersen, K., Johnson, S., Buuren, N.V., Chauvin, A., 2014. Creating a sustainability scorecard as a predictive tool for measuring the complex social, economic and environmental impacts of industries, a case study: assessing the viability and sustainability of the dairy company $A$. Journal of Environment Management, Vol. 133, pp. 184-192.

[27] Sanders, J.L., Linderman, K., 2014. Process management, innovation and efficiency performance. Business Process Management Journal, Vol. 20 (2), pp. 335-358.

[28] Chesbrough, H., 2006. Open Innovation: a New Paradigm for Understanding Industrial Innovation. Open Innovation: Researching a New Paradigm. Oxford University Press, Oxford.

[29] Zemaitis, E., 2014. Knowledge management in open innovation paradigm context: high tech sector perspective. Proc. Soc. Behav. Sci, Vol. 110, pp. 164-173.

[30] Seethamraju, R., Marjanovic, O., 2009. Role of process knowledge in business process improvement methodology: a case study. Bus. Process Manag. J. Vol. 15 (6), pp. 920-936.

[31] Cui, T., Ye, H., Teo, H.H., Li, J., 2015. Information technology and open innovation: a strategic alignment perspective. Inf. Manag, Vol. 52 (3), pp. 348-358.

[32] Niehaves, B., 2010. Open process innovation: the impact of personnel resource scarcity on the involvement of customers and consultants in public sector BPM. Bus. Process Manag. J., Vol. 16 (3), pp. 377-393.

[33] Jones, J.L.S., Linderman, K., 2014. Process management, innovation and efficiency performance: the moderating effect of competitive intensity. Bus. Process Manag. J., Vol. 20 (2), pp. 335-358.

[34] Madrigal-Sanchez, J., Quesada-Pineda, H., 2012. Innovation: case study among wood, energy and medical firms. Bus. Process Manag. J., Vol. 18 (6), pp. 898-918.

[35] Kim, B., Kim, E., Foss, N.J., 2015. Balancing absorptive capacity and inbound open innovation for sustained innovative performance: an attention-based view. Eur. Manag. J., Vol. 34 (1), pp. 80-90.

[36] Mehralian, G., Rajabzadeh, A., Reza Sadeh, M., \& Reza Rasekh, H., 2012. Intellectual capital and corporate performance in Iranian pharmaceutical industry. Journal of Intellectual Capital, Vol. 13 (1), pp. 138-158.

[37] Chesbrough, H.W., 2003. Open Innovation: The New Imperative for Creating and Profiting from Technology. Harvard Business School Press, Boston, MA. 
[38] Fatma Genç Ünay, Cemal Zehir, 2012. Innovation intelligence and entrepreneurship in the fashion industry. Social and Behavioral Sciences, Vol. 41, pp. 315 - 321.

[39] Aino Kiantoa, Josune Sáenz, Nekane Aramburu, 2017. Knowledge-based human resource management practices, intellectual capital and innovation. Journal of Business Research journal, Vol. 81, pp. 11-20.

[40] Iwai, Katsuhito, 1984. Chumpeterian Dynamic. An Evolutionary Model of Innovation and Imitation. Journal of Economic Behavior and Organization, Vol. 5, pp. 159-190.

[41] Shumpeter, J.A., 1961. The theory of economic development (English translation of Theorie der Wirtschaftlichen Entwicklung, 1992). Oxford University Press, Oxford.

[42] Lesáková, Lubica, 2014. Evaluating innovations in small and medium enterprises in Slovakia. Social and Behavioral Sciences, Vol. 110, pp. 74 - 81.

[43] Sharda, R., Delen, D., \& Turban, E., 2014. Business intelligence and analytics: systems for decision support. 10th ed. USA: Prentice Hall. ISBN-10: 0133050904.

[44] Bock, G. W., Zmud, R. W., Kim, Y. G., \& Lee, J. N., 2005. Behavioural intention formation in knowledge sharing: examining the roles of extrinsic motivators, socialpsychological forces, and organizational climate. MIS Quarterly, Vol. 29 (1), pp. 87111.

[45] Maryam Alavi, Dorothy E. Leidner., 2001. Review: Knowledge Management and Knowledge Systems: Conceptual Foundations and Research Issue. MIS Quarterly, Vol. 25 (1), pp. 107-136.

[46] Frost, A., 2014. A synthesis of knowledge management failure factors. Retrieved July 2005 from (https://www.knowledge-management-tools.net).

[47] Goodhue, D. L., 1995. Understanding user evaluations of information systems. Management Science, Vol. 41 (12), pp. 1827-1844.

[48] Akhavan, P., Jafari, M., \& Fathian, M., 2005. Exploring failure-factors of implementing knowledge management systems in organizations. Journal of Knowledge Management Practice, Vol. 6 (5), pp. 1-8.

[49] Brelade, S. and Harman, C., 2003. A Practical Guide to Knowledge Management. Thorogood, London.

[50] Pathirage, C., Haigh, R., Amaratunga, D. and Baldry, D., 2008. Knowledge management practices in facilities organisations: a case study. Journal of Facilities Management, Vol. 6 (1), pp. 5-22.

[51] Tucker, M., 2008. Building FM productivity through knowledge management. Journal of Facilities Management, Vol. 6 (1).

[52] Kebede, G., 2010. Knowledge management: an information science perspective. International Journal of Information Management, Vol. 30 (5), pp. 416-424. 
[53] . Ajmal, M., Helo, P. and Kekale, T., 2010. Critical factors for knowledge management in project business. Journal of Knowledge Management, Vol. 14 (1), pp. 156-168.

[54] Kluge, J., Stein, W. and Licht, T., 2001. Knowledge Unplugged. The McKinsey \& Company: Global Survey on Knowledge Management. Palgrave, Basingstoke.

[55] Bessant, J. and Francis, D., 1999. Using learning networks to help improve manufacturing competitiveness. Technovation, Vol. 19 (6/7), pp. 373-81.

[56] Davenport, T.H., 1994. Saving IT's soul: human centered information management. Harv. Bus. Rev., Vol. 72 (2), pp. 119-131.

[57] Dow, R.M., Pallaschke, S., 2010. Managing knowledge for spacecraft operations at ESOC. J. Knowl. Manag, Vol. 14 (5), pp. 659-677.

[58] López-Nicolás C., Merono-Cerdán A.L., 2011. Strategic knowledge management, innovation and performance. Int. J. Inf. Manag, Vol. 31 (6), pp. 502-509.

[59] Cátia Milena Lopes, Annibal Scavarda, Luiz Fernando Hofmeister, Antônio Márcio Tavares Thomé, Guilherme Luís Roehe Vaccaro, 2016. An analysis of the interplay between organizational sustainability, knowledge management, and open innovation. Journal of Cleaner Production, Vol. xxx, pp. 1-13.

[60] Hurley, R.F., Hult, G.T.M., 1998. Innovation, market orientation, and organizational learning: an integration and empirical examination. Journal of Marketing, Vol. 62, pp. 42-54.

[61] Szeto, E., 2000. Innovation capacity: working towards a mechanism for improving innovation within an inter-organizational network. The TQM Magazine, Vol. 12 (2), pp. 149-57. 